\title{
Allozyme variability in a central Anatolian honeybee (Apis mellifera L) population
}

\author{
I Kandemir, A Kence* \\ Department of Biology, Middle East Technical University, 06531 Ankara, Turkey
}

(Received 1st September 1994; accepted 10 September 1995)

\begin{abstract}
Summary - Central Anatolian honeybees (Apis mellifera $L$ ) were electrophoretically examined at 6 enzyme loci. Four loci were polymorphic ( $E s t-3, P g m, H k$, and $M d h$ ) and 2 loci were found to be monomorphic ( $P g i$ and $M e$ ). Genotypic frequencies of enzymes met Hardy-Weinberg expectations. Low levels of genetic variability were detected and heterozygosity was calculated as $0.033 \pm 0.005$. Gene frequencies obtained for Pgm, Est, Hk and Mdh were compared with those of the studies done in other parts of the world, especially in neighboring countries.
\end{abstract}

central Anatolian honeybee / Apis mellifera L / isozyme / genetic variation / starch-gel electrophoresis

\section{INTRODUCTION}

Bodenheimer (1941) were the first to attempt to classify honeybees of Anatolia based on morphometric data for the first time. Later, Maa (1953) published a formal taxonomic classification of Anatolian honeybees based on 3 museum specimens. Adam (1983) and Ruttner (1987) suggested that there were 3 different honeybee races in Turkey: Apis mellifera anatoliaca in central Anatolia, Apis mellifera caucasica in the North East and Apis mellifera meda in the South East (border with Syria, Iraq and Iran).

The extensive practice of migratory beekeeping is now mixing all 3 races in Turkey.
A report by the Development Foundation of Turkey (TKV) mentioned that $90 \%$ of commercial beekeepers practice migratory beekeeping (Inci, 1987). During these migrations different honeybee races can hybridize with isolated local honeybee populations.

Enzyme polymorphisms in honeybees have been studied extensively within the last 2 decades. However, no study has been conducted on enzyme polymorphism in Turkish honeybees. Enzyme polymorphisms have been useful in the classification of honeybees. The objectives of this study were to determine the extent of electrophoretic variation in 6 enzyme systems and compare enzyme polymorphisms of the central

\footnotetext{
* Correspondence and reprints
} 
Anatolian honey bees to those already studied in subspecies from other regions (Badino et al, 1983, 1985; Sheppard and McPheron, 1986; Sheppard, 1988; Del Lama et al, 1990).

\section{MATERIALS AND METHODS}

Honeybee samples were collected in August and September 1992 in Bala. Bala is located in central Anatolia, $70 \mathrm{~km}$ south of Ankara and is $2647 \mathrm{~km}^{2}$ in size. It has a semi-arid climate, little vegetation and there are many small hills between villages. Villages are visited by migratory beekeepers from different provinces in early summer. Other regions are never visited by migratory beekeepers. Villagers still keep their colonies in traditional trunk hives. Thirty-nine villages were visited and apiaries from 43 different locations were sampled. In each apiary 4-6 honeybee workers were sampled from the entrance of each hive (Biasiolo and Comparini, 1990). Sample size ranged between 19-55 and the total number of individuals sampled was 1501 . They were put in small labeled boxes and kept in an ice box. The thoraces of honeybees were ground and homogenates were kept at $-20^{\circ} \mathrm{C}$ until needed for electrophoresis. Six enzyme systems, MDH (malate dehydrogenase, EC 1.1.1.37), ME (malic enzyme, EC 1.1.1.40), PGM (phosphoglucomutase, EC 5.4.2.2 formerly EC 2.5.7.11), PGl (phosphoglucose isomerase, EC 5.3.1.9), EST (esterase, EC 3.1.1), and HK (hexokinase, EC 2.7.1.1), were studied by starch-gel electrophoresis. Three enzyme systems (EST, PGI, HK) were studied using the Triscitrate, $\mathrm{pH} 7.0$ buffer system (Shaw and Prasad, 1970; Del Lama, 1988), 2 enzyme systems (MDH and $\mathrm{ME}$ ) were studied using the Tris- $\mathrm{HCl}, \mathrm{pH} 8.6$ buffer system (Shaw and Prasad, 1970; Smith et al, 1972) and PGM was studied using the TrisEDTA-maleate-magnesium, $\mathrm{pH} 7.4$ buffer system (Shaw and Prasad, 1970). Gel and sample preparation and experimental conditions have been reported in previous papers (Shaw and Prasad, 1970; Del Lama, 1988). Enzyme activity was visualized by the techniques of Harris and Hopkinson (1976). Gene frequencies, enzyme heterozygosities and population heterozygosities were calculated according to Nei (1987). The test goodness of fit of gene frequencies to Hardy-Weinberg expectations was carried out using $\chi^{2}$ analysis (Sokal and Rohlf, 1981).

\section{RESULTS}

Of the 6 enzyme systems assayed with horizontal starch-gel electrophoresis, 4 were polymorphic, and 2 exhibited invariant banding patterns in Bala (Central Anatolia honeybee populations). All isozymes are designated using relative mobilities with respect to the most common isozyme used as standard (mobility 100) (table I). Populations of honeybees of Bala were found to be in Hardy-Weinberg equilibrium with respect to all polymorphic enzymes $\left(\chi^{2}\right.$-test, $\left.P<0.05\right)$.

\section{Pgm locus}

$P g m$ exhibited 2 alleles, Pgm-75 and Pgm100 , according to their relative mobilities in the present study. Del Lama et al (1985) first reported the presence of 3 alleles at this locus; Pgm-F, Pgm-M and Pgm-S in the order of decreasing electrophoretic mobility in Africanized bee populations and 2 alleles in $A m$ carnica originating from Germany. The alleles found in this study probably correspond to the Pgm-M and Pgm-F described in Del Lama et al (1985). Meixner et al (1994) found 3 alleles $(P g m-75, P g m-100$ and Pgm120 ) in Kenya, of which Pgm-120 was previously unreported. The frequency of the most common allele ranged between 0.757 and 0.986 in 30 polymorphic locations.

\section{Est-3 locus}

The Est-3 locus exhibited 3 alleles, Est-70, Est-100 and Est-130 as reported previously in Czechoslovakian honeybees by Sheppard and McPheron (1986) and in Kenya (Meixner et al, 1994). These alleles correspond to Est-S, Est-M and Est-F, respectively, in A m ligustica (Badino et al, 1985) and in Greek honeybees (Badino et al, 1988). The frequency of the most common allele at the 8 polymorphic locations ranged between 0.921 and 0.988 . 


\section{Mdh locus}

This enzyme has 5 alleles (Mdh-65, Mdh87, Mdh-100, Mdh-116 and Mdh-133) in Bala, central Anatolia. Five alleles Mdh-55, Mdh-65, Mdh-80, Mdh-87 and Mdh-100 were detected by different authors in different honeybee populations (Contel et al, 1977; Cornuet, 1979; Gardside, 1980; Nunamaker and Wilson, 1981; Badino et al, 1983; Nunamaker et al, 1984; Sheppard and Berlocher, 1984, 1985; Badino et al, 1985; Sheppard and McPheron, 1986; Badino et al, 1988; Sheppard, 1988; Lobo et al, 1989; Meixner et al, 1994). The frequency of the most common allele ranges between 0.821 and 0.988 in the 12 locations where this enzyme is polymorphic.

\section{Hk locus}

Hexokinase has 4 alleles ( $H k-87, H k-100$, $H k-110$ and $H k-120$ ). This enzyme has been studied previously by Del Lama et al (1988) and they found 2 alleles ( $H k-87$ and $H k-100$ ) in Africanized honeybees in Brazil. This locus was also studied in Kenya by Meixner et al (1994), who reported the presence of 2 alleles $(H k-83$ and $H k-100)$. The frequency of the most common allele in the 14 locations where this enzyme was polymorphic ranged between 0.786 and 0.991 .

\section{Pgi and Me loci}

Pgiand Me were invariant in the central Anatolian populations. The Pgilocus was studied by Badino et al (1983, 1985, 1988), and no genetic variability was detected. Me variability was reported by Sheppard and Berlocher (1984; 1985) and Sheppard and McPheron (1986). Three alleles were reported (Me-79, Me-100 and Me-106) in A mellifera from Norway (Sheppard and Berlocher, 1984), Italy (Sheppard and Berlocher, 1985) and westem
Czechoslovakia (Sheppard and McPheron, 1986). The Me locus is found nearly fixed in Kenya. In one colony, however, a previously unknown allele, Me-117, was found (Meixner et al, 1994).

Heterozygosities of locations ranged between 0.004 and 0.157 . Overall average heterozygosity for central Anatolia was calculated as $0.033 \pm 0.005$.

\section{DISCUSSION}

In this study, a population honeybees from Bala was studied extensively at 43 locations. A total of 1501 honeybee individuals were analyzed electrophoretically. Central Anatolian honeybee populations showed a low level of genetic variability in accordance with the studies on honeybees from other countries. Among the enzyme loci studied, the Pgm locus was the most polymorphic. For $H k$ and $M d h 2$, new alleles were discovered in this work.

The Pgm locus was studied in a number of populations by Mestriner and Contel (1972), Brueckner (1974), Contel et al (1977), Nunamaker (1980), Nunamaker and Wilson (1980), Badino et al (1983), Sheppard and Berlocher (1985), and Sylvester (1986). None of these authors reported any variability at the Pgm locus in honeybees. Del Lama et al (1985) first reported variation at $P g m$ and found that the frequency of the fast allele was 0.926 in Africanized honeybees, 0.962 in Carniolan honeybees imported from Germany, and 1.000 in $A$ m ligustica. In a later study Sheppard et al (1991) studied Brazilian honey bees and reported that the previous 'fast' and 'medium' alleles of Del Lama corresponded to relative mobilities of $1.0(P g m-100)$ and 0.75 (Pgm-75), respectively. In our study, the slow allele (Pgm-75) was the common allele and the fast allele (Pgm-100) was rare.

Variation in the Est locus was similar to that reported for Greek honeybees (Badino et 


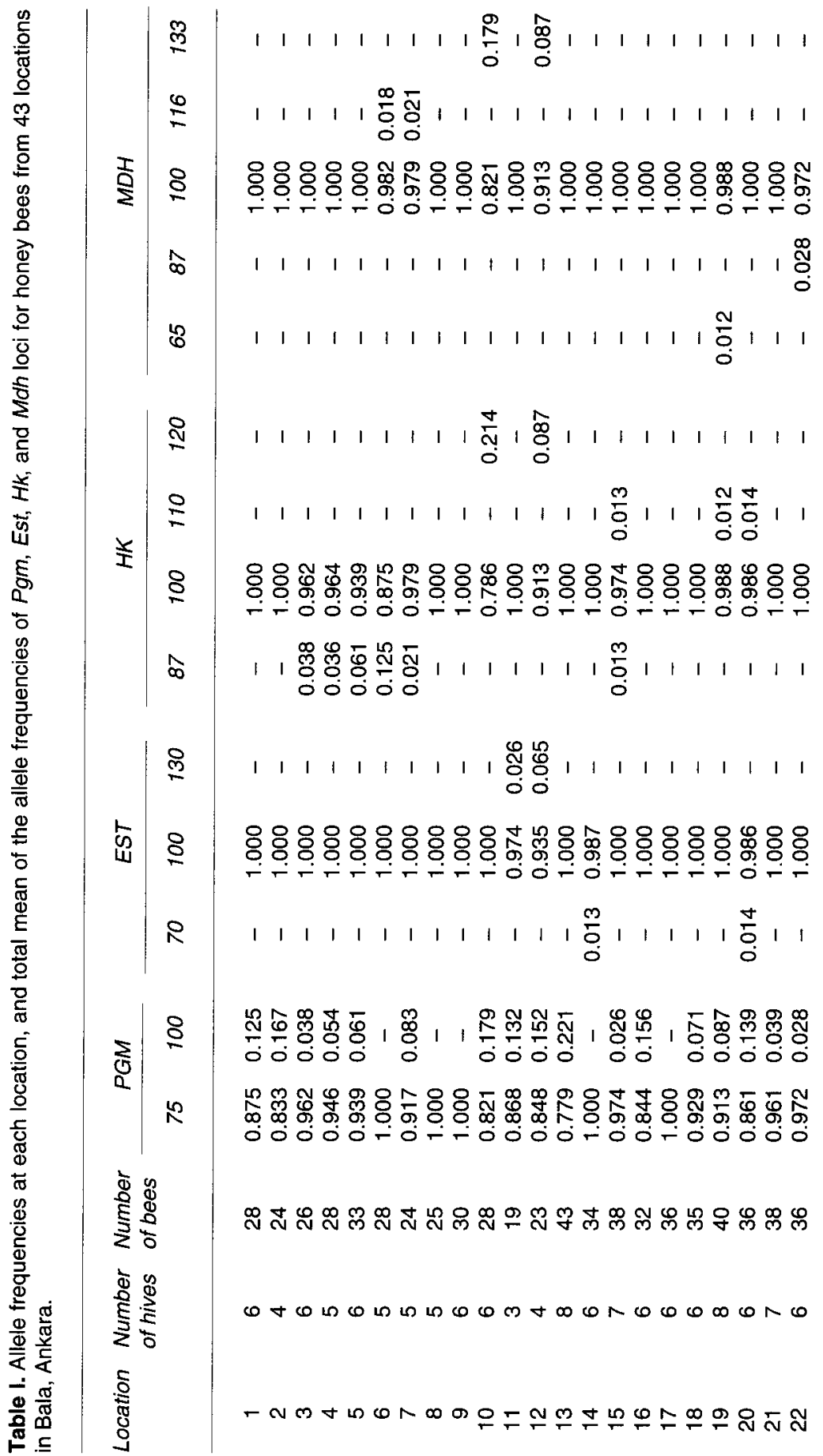




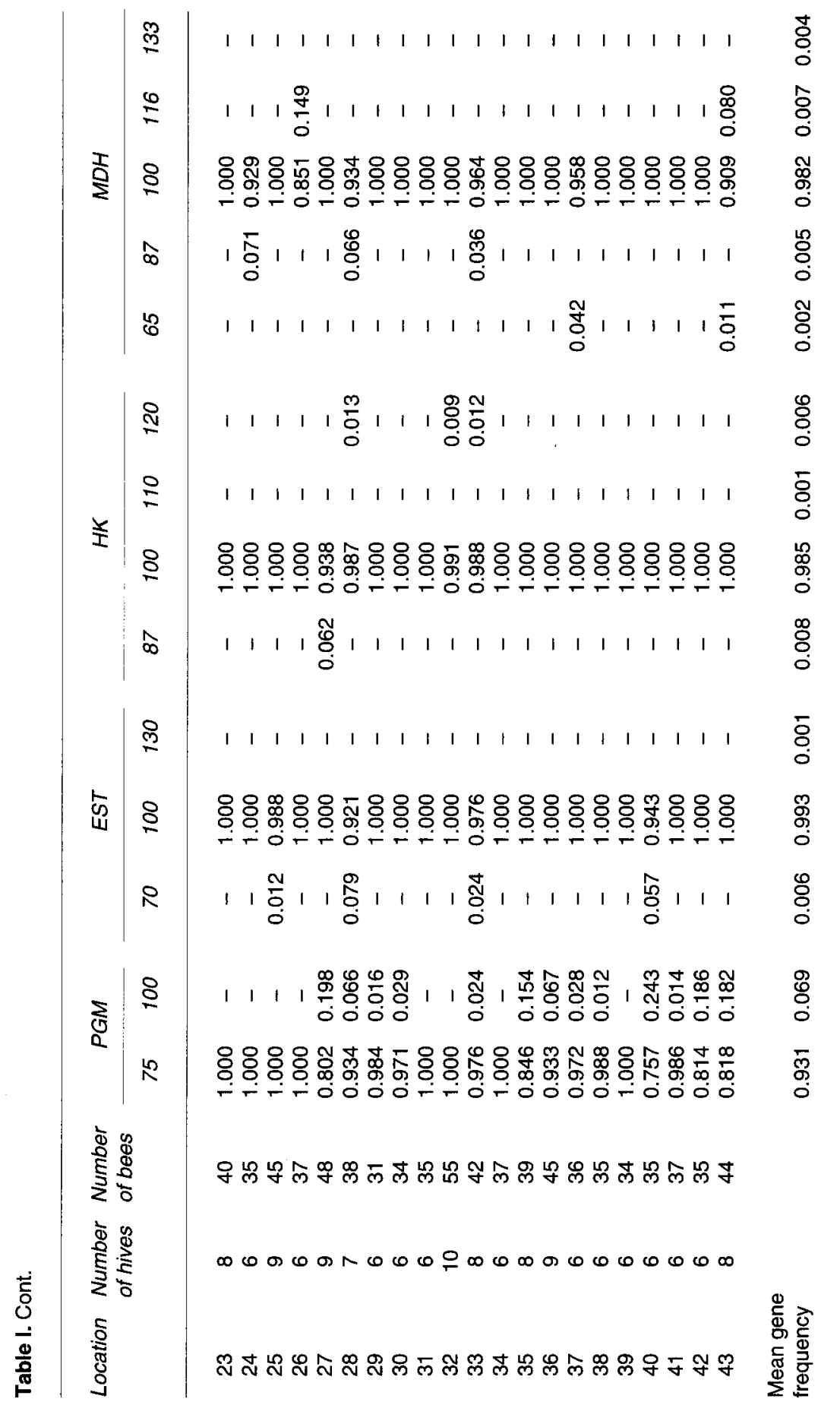


al, 1988). In this study, Est-70 was rare and only found at 6 locations out of 43. Est-100 was the most frequent allele and was fixed at 35 locations. Est-130 was the other rare allele and was found at only 2 locations. Del Lama et al (1990) found gene frequencies similar to the present study in Africanized honeybees and European races of $A$ mellifera L. Badino et al (1985) found similar gene frequencies in honeybees in northern Italy, but gene frequencies in samples of western and eastern Sicily were quite different from findings of Sheppard and Berlocher (1985), Badino et al (1988), Del Lama et al (1990), and the present study. The frequency of Est-70 decreases and the frequency of Est-100 increases as one goes from western to eastern Sicily (Badino et al, 1985).

In Hk locus we observed 2 alleles (Hk110 and $H k-120)$ in addition to those observed by Del Lama et al (1985, 1990). The frequency of $H k-110$ ranged between 0.012 and 0.014 in the 3 locations where this allele was found. The frequency of $H \mathrm{k}$ 120 varied between values 0.009 and 0.214 at 4 locations. $H k-100$ was the most frequent allele in central Anatolian honeybees. This allele was fixed in European honeybees, whereas, in Africanized honeybees the frequency of $H k-100$ ranges between 0.348 and 0.600 (Del Lama et al, 1990).

We found 5 alleles at the Mdh locus ( $M d h$ 65, Mdh-87, Mdh-100, Mdh-116 and Mdh133). Sheppard (1988) reported $3 \mathrm{Mdh}$ alleles in US honeybee populations and they were named as Mdh-65, Mdh-80 and Mdh100. Sheppard and Berlocher (1985) also reported $M d h-87$ in A $m$ ligustica. Cornuet (1983) demonstrated a north to south cline in gene frequencies of $M d h-80$ in A m iberica. In Europe, including northern Spain, the frequency of $M d h-80$ is very high and the frequency of $M d h-80$ decreases towards southern Spain. Nielsen et al (1994) showed a similar cline in Mdh-80 in California and mentioned parallel clines in Europe, North America and South America. We could not detect
Mdh-80 in our study. We observed $M d h-87$ in 4 out of 43 locations. Mdh- 100 was fixed in 31 locations and variable in 12 locations. In contrast to our findings, in $A$ m carnica and $A m$ ligustica the frequency of $M d h-100$ was rather low, and the most common allele for these subspecies was Mdh-65 (Sheppard and Berlocher, 1985; Sheppard, 1988; Del Lama et al, 1990). In Greece, the frequency of $M d h-100$ decreased going north through Peloponnesos to Macedonia, but remained high in the eastern region near the border to Turkey; in Crete this allele was fixed (Badino et al, 1988). Although Mdh100 was nearly fixed in central Anatolia, in a sample from Igneada located in northwest Turkey, like the honeybee populations in northeast Greece, the frequencies of $M d h$ 100 and Mdh-65 were 0.622 and 0.378 , respectively (unpublished data). The $M d h$ 116 and $M d h-133$ found in this study have not been reported previously. Badino et al (1985) found another fast allele, which he called $F 1$ in eastern Sicily and Calabria. This $F 1$ allele may correspond to one of the fast alleles (Mdh-116 or Mdh-133) present in this study. Ndiritu et al (1986) reported $3 \mathrm{Mdh}$ alleles (Mdh-100, Mdh-95 and Mdh-80) in African honeybees from Kenya. We do not know whether there is a correspondence between the Mdh alleles found in Kenya and in our study. However, Mdh-100 was the most common allele in both studies.

The Mdh-100 gene frequency in central Anatolian honeybees is close to the gene frequencies of Africanized honeybees. The Mdh-65 gene frequency, which is low in central Anatolian and Africanized honeybees, is common in $A$ m ligustica and $A m$ carnica. The Hk locus also shows variation in both central Anatolian and Africanized honeybees, whereas $H k-100$ is fixed in $A m$ ligustica and $A m$ carnica. This seems to support the hypothesis (Ruttner et al, 1978) on the historical biogeography of honeybees that suggests honeybees dispersed from a center situated in the north east of Africa to 
the near east. However, it would be premature to speculate about the evolutionary history of honeybees based on allozyme data from a single population. Studies on geographic variation of isozymes in the honeybees Turkey on a wider scale are under way.

\section{ACKNOWLEDGMENTS}

The authors wish to thank G Eren-Kandemir who assisted during collection and preparation for the electrophoresis. We thank to M Kence and CC Bilgin for their critical advice. We would like to thank the Development Foundation of Turkey (TKV) for their help in collection of samples. We would like to thank apiaries in Bala for supplying bee material. This work was supported by Turkish Scientific Research Council (Project No TBAG/1021).

\section{Résumé - Variabilité allozymique dans} une population d'abeilles d'Anatolie centrale. Les analyses électrophorétiques des allozymes ont montré peu de variabilité génétique chez l'abeille. On a recherché la variabilité génétique de 6 systèmes enzymatiques de populations d'abeilles d'Anatolie centrale : enzyme malique $(M e)$, phosphoglucomutase ( $P g m$ ), estérase-3 (Est-3), hexokinase $(H k)$, phosphogluco-isomérase (Pgi), malate-déshydrogénase (Mdh). Des électrophorèses sur gels d'amidon ont été réalisées. L'activité enzymatique a été visualisée par la technique de Harris et Hopkinson (1976). La fréquence des gènes et l'hétérozygotie ont été calculées. L'équilibre de de Hardy-Weinberg a été testé. Sur les 6 systèmes étudiés, 4 se sont montrés polymorphes (Pgm, Est-3, Mdh, Hk). À l'exception de $M d h$ qui a une structure dimère, tous les enzymes polymorphes sont des monomères. Tous les enzymes respectent l'équilibre de Hardy-Weinberg. L'hétérozygotie était de $0,033 \pm 0,005$. Les populations d'abeilles d'Anatolie centrale ont présenté un faible niveau de variabilité génétique. Les fréquences de gènes pour $M d h$ et $H k$ se situent entre les fréquences trouvées en Europe et en Afrique.

abeille d'Anatolie centrale / Apis mellifera L / allozyme / variabilité génétique / électrophorèse sur gels d'amidon

Zusammenfassung - Allozymvariabilität in einer Population zentralanatolischer Honigbienen (Apis mellifera L). Zur Bestimmung der genetischen Variabilität in einer zentralanatolischen Population von Honigbienen wurden sechs Enzymsysteme untersucht (Malat-Enzym, Phosphoglucomutase, Esterase-3, Hexokinase, Phosphogluco-isomerase, Malatdehydrogenase). Die elektrophoretische Untersuchung ergab eine sehr geringe genetische Variabilität mit einem errechneten Heterozygotiegrad von $0.033 \pm 0.005$. Das Isoenzymbandenmuster wurde mit Stärkegel-Elektrophorese ermittelt. Die Enzymaktivität wurde mit der Technik von Harris und Hopkinson (1976) sichtbar gemacht. Die Genfrequenzen und der Heterozygotiegrad wurden berechnet, sowie die Übereinstimmung mit den Erwartungswerten nach Hardy-Weinberg überprüft. Vier der sechs Enzymsysteme (Pgm, Est-3, Mdh, $H$ H) waren polymorph. Außer Mdh, das eine dimere Struktur hatte, waren alle polymorphen Enzyme monomer. Bezüglich aller vier polymorphen Enzymloci befand sich die Population im Hardy-Weinberg Gleichgewicht. Die für Pgm, Est, Hk und Mdh bestimmten Genfrequenzen wurden mit den Ergebnissen aus Untersuchungen in anderen Weltteilen, besonders aber aus benachbarten Ländern, verglichen.

zentralanatolische Honigbienen / Apis mellifera L / Isoenzyme / genetische Variabilität / Stärkegel-Elektrophorese

\section{REFERENCES}

Adam BR (1983) In Search of the Best Strains of Honey Bees (2nd ed), Northern Bee Books, UK 
Badino G, Celebrano G, Manino A (1983) Population structure and $M d h-1$ locus variation in Apis mellifera ligustica. J Hered 74, 443-446

Badino G, Celebrano G, Manino A, Longo S (1985) Enzyme polymorphism in the Sicilian honeybee. Experientia 41, 752-754

Badino G, Celebrano G, Manino A, Ifantidis MD (1988) Allozyme variability in Greek honeybees (Apis mellifera L). Apidologie 19, 337-386

Biasiolo A, Comparini A (1990) Esterase-6 locus, a new enzyme polymorphism in Apis mellifera. Apidologie $21,123-126$

Bodenheimer FS (1941) Studies on the honeybee and beekeeping in Turkey, Merkez Ziraat Mücadele Enstitüsü, Ankara

Brueckner D (1974) Reduction of biochemical polymorphisms in honeybee (Apis mellifera). Experientia 30 618-619

Contel EPB, Mestriner MA, Martins E (1977) Genetic control and developmental expression of malate dehydrogenase in Apis mellifera. Biochem Genet $15,859-876$

Cornuet JM (1979) The MDH system in honey bees of Guadaloupe. J Hered 70, 223-224

Cornuet JM (1983) Reproduction génétique et sélection de l'abeille. Bull Tech Apic 10, 13-36

Del Lama MA, Mestriner MA, Pavia JCA (1985) Est-5 and Pgm1: new polymorphisms in Apis mellifera. Rev Brazil Genet 8, 17-27

Del Lama MA, Figueiredo RA, Soares AEE, Del Lama SN (188) Hexokinase polymorphism in Apis mellifera and its use for Africanized honeybee identification. Rev Brazil Genet 11, 287-297

Del Lama MA, Lobo JA, Soares AEE, Del Lama SN (1990) Genetic differentiation estimated by isozymic analysis of Africanized honeybee populations from Brazil and from Central America. Apidologie 21, 271-280

Gartside DF (1980) Similar allozyme polymorphism in honeybees (Apis mellifera) from different continents. Experientia 36, 649-650

Harris H, Hopkinson DA (1976) Handbook of Enzyme Electrophoresis in Human Genetics. North-Holland, Amsterdam

Inci A (1987) Beekeeping in the world and Turkey and the integrated beekeeping project of Development Foundation of Turkey. In: Training Course on Apiculture (Beekeeping and Honey Processing) at the Development Foundation of Turkey, Kazan, Development Foundation of Turkey, Ankara

Lobo JA, Del Lama MA, Mestriner MA (1989) Population differentiation and racial admixture in the Africanized honeybee (Apis mellifera L). Evolution 43, 794-802

Maa T (1953) An inquiry into the systematics of the tribus Apidini or honeybees (Hymenoptera). Treubia 21 , 525-640

Meixner MD, Sheppard WS, Dietz A, Krell R (1994) Morphological and allozyme variability in honey bees from Kenya. Apidologie 25, 188-202
Mestriner MA, Contel EPB (1972) The P-3 and Est loci in the honeybee Apis mellifera. Genetics 72, 733-738

Ndiritu DW, Mutugi N, Ndung'u S (1986) Variation in malate dehydrogenase allozymes among honeybee populations in Kenya. J Apic Res 25, 234-237

Nei M (1987) Molecular Evolutionary Genetics. Columbia University Press, New York

Nielsen D, Page Jr E, Crosland MWJ (1994) Clinal variation and selection of MDH allozymes in honey bee populations. Experientia 50, 867-871

Nunamaker RA (1980) Subspecies determination in the honeybee (Apis mellifera $\mathrm{L}$ ) based on isoelectric focusing of malate dehydrogenase. PhD Dissertation, University of Wyoming, Laramie, WY

Nunamaker RA, Wilson WT (1980) Some isozymes of the honeybee. Isozyme Bull 13, 111-112

Nunamaker RA, Wilson WT (1981) Comparison of MDH allozyme patterns in the African honey bee (Apis mellifera adansonii $\mathrm{L}$ ) and the Africanized populations of Brazil. J Kansas Entomol Soc 54, 704-710

Nunamaker RA, Wilson WT, Haley BE (1984) Electrophoretic detection of Africanized honey bees (Apis mellifera scutellata) in Guatemala and Mexico based on malate dehydrogenase allozyme patterns. $J$ Kansas Entomol Soc 57, 622-631

Ruttner F, Tassencourt L, Louveaux J (1978) Biometrical-statistical analysis of the geographic variability of Apis mellifera L. Apidologie 9, 363-381

Ruttner F (1988) Blogeography and Taxonomy of Honeybees. Springer-Verlag, Berlin

Shaw CR, Prasad R (1970) Starch gel electrophoresis a compilation of recipes. Biochem Genet 4, 297-320

Sheppard WS, Berlocher SH (1984) Enzyme polymorphism in Apis mellifera from Norway. J Apic Res 23, 64-69

Sheppard WS, Berlocher SH (1985) New allozyme variability in Italian honey bees. J Hered 76, 45-48

Sheppard WS, McPheron BA (1986) Genetic variation in honey bees from an area of racial hybridization in western Czechosłovakia. Apidologie 17, 21-32

Sheppard WS (1988) Comparative study of enzyme polymorphism in United States and European honey bee (Hymenoptera: Apidae) populations. Entomol Soc Am 81, 886-889

Sheppard WS, Soares AEE, DeJong D, Shimanuki H (1991) Hybrid status of honey bee populations near the historic origin of Africanization in Brazil. Apidologie 22, 643-654

Smith M, Hopkinson DA, Harris $H$ (1972) Alcohol dehydrogenase isozymes in adult human stomach and liver: evidence for activity of the $A D H 3$ locus. Ann Hum Genet 35, 243-253

Sokal RR, Rohlf FC (1981) Biometry. WH Freeman and Company, San Francisco, CA

Sylvester HA (1986) Biochemical genetics. In: Bee Genetics and Breeding (T Rinderer, ed), Academic Press, Orlando, FL, 177-203 